\title{
Some Economic Aspects of Business Environment in Albania
}

\author{
Dr. Matilda Veliu
}

"Ismail Qemali" University of Vlora-Albania; matilda.veliu@univlora.edu.al

\section{Doi:10.5901/mjss.2016.v7n1p279}

\begin{abstract}
Doing business in Albania, as a country that has suffered by a long economic transition, is not so easy. The most crucial agents of economic game: government and business are going to be in the bad situations that they ever been. The role of state is so decisive. By the status that it have, is it duty to take fiscal and monetary policies in order to create a favorable climate of business. Especially, regards of competitive environment. Something is sure: if the business is in good condition, also the government will be and will perform its duties in high level. But, how is the reality and what steps has undertake the government by this point of view, will be the focus of this article. For this reason, a questionnaire has been created and distributed in the most great area of the country, in order to get more information and to evaluate the probably correlation that must be exists among the variables that explain the situation. The econometric model will be created with the aim to stress which is the most effective macroeconomic policy, fiscal or monetary policy, under the current economic situation in Albania. The aim of article is to examine which is the macroeconomic policy that contributes in the improvement of firm's situation.
\end{abstract}

Keywords: Business environment, monetary and fiscal policy, fiscal instruments, structural change, unemployment.

\section{Introduction}

Widely is accepted, by the economics, that the business development is the promoter of the growth's economy. Fiscal policy with its instruments, is seen as a necessity today in Albania in order to reduce the informal economy, also the level of unemployment. As a consequence, the opportunities that people have better life tend to rise by the grater revenues. But the standard of living of citizens is not conditioned only by these factors, but also by others, such as the level of inflation, the rate of saving, interest rate in the financial markets etc. Consequently, the effectiveness of fiscal policies of a country will depend largely on the performance of these variables, also by those in other countries where import-export is in high level.

How are seen those fiscal measures by business, also the perception level of the good results of strategies, are some other conditions that determinate the performance of those. Obviously, creating a better climate for business operations in the country is a primary objective in order to ensure a sustainable economic growth, especially over time. The presence of state in the economy is indisputably. The problem is to choose that strategy that's enables the achievement of objectives with little negative effect on the other macroeconomic variables. The mix strategy depends a lot by the actual condition of the economy. The economics agree that, to have the growth it's necessary to stimulate the business that contributes in the reduction of the unemployment rate. So, those strategies which can increase the level of firm's investments, perhaps are the best ways to do something good in the economy. In this point of view, the fiscal policy seems to be more preferred that monetary policy, as have to do directly with the cost of production of the firms. But is not to leave aside the monetary policy, which is more flexible (the financial market tends to be more flexible than the market of goods and services) and have great impact on the economy.

The study aims to identify which is the more appreciate between those policies, and how favorable is the climate of doing business in Albania. The method used to collect information regards the matter is the survey by the questionnaire. The aim of choosing that method was because, it has to do directly with the firms and the information that will be collect by it will have to do directly with the issues. The questions in the survey are been formulated using the Licert Scale in the answers. The questionnaire was made by 5 sections, including general information for the company, service to the clients, financial section, taxation, regulator environment and infrastructure section. The questionnaire was distributed in several big cities of the country, such as Vlora, Saranda, Tirana, Gjirokastra and Shkodra. Those cities are the areas where the firms are very concentrated, so the results can give us a good idea of how favorable is the economic environment in it, despite the opinions. The data will be evaluated according to the objectives of the article, with a coefficient of error $5 \%$. 


\section{Literature Review}

Taking in consideration the actual economic situation of the country, is necessary to think about that policy that contributes to the long run growth. This is a challenge, because short term recovery requires increased in demand while the long run requires increased in supply. The difference is important as short term taxes concessions can be hard to reserve, implying that policies to alleviate the crisis could compromise long run growth (Johansson et al, 2008). As a country which has many resources not used for the production, the possibility to be recovered by the crisis is much more than the others where the crisis is more evident. The problem is to choose that strategy that will contribute to the growth, especially in the long run term.

In practice, is difficult to distinguish between the effect of tax policy on the levels and on growth rates of GDP. That's complicate choosing the macroeconomic strategies. If the tax changes that encourage innovation and entrepreneurship may have persistent long run growth effect, while those that effect investment also can have impact on short run and long run growth. The changes on the structure of taxes can influence better than the level of taxes (\% Tax/ $\% G D P)$. It has two advantages:

$>$ It's easy to be measured statistically

The tax structure has directly impact on the labor supply, which has an increased effect over the time.

The country for about eight year has applied the flat tax. That strategy was created with the aim to contribute a lot in the country budget. This not happened. Perhaps by some reasons:

$>$ Some groups were out of taxation

$>$ The rich people became more rich than before and the poor people more poor then before

$>$ In the strategies was not evident the social dimension in the distribution of the tax revenues

Now the country has applied the progressive taxes which put away the negative effects of flat tax. But the empirical studies from developed countries suggest a negative relationship between tax rate and economic growth. McBride (2012) reviewed twenty-six of such studies and found a negative effect of taxes on economic growth, at almost $90 \%$ of those. He concluded that these empirical evidence on tax and growth support the Neo-Classical view that income and wealth must first be produced and then consumed, meaning that taxes on the factors of productions, i.e., labor and capital, are particularly disruptive of wealth creation.

By the other hand, Arnold et al, (2011) stress that progressive taxation reduces investments, risk taking and entrepreneur activity since a disproportionately large share of these activities is done by high income earners. Schoemann and Koch (2005) estimated the impact on economic growth of changes in direct and indirect taxes on the developing countries and found that the economic growth is negatively affected by direct taxes while indirect taxes has no significant effect on growth.

Despite that exist a debate between choosing flat tax or progressive tax, the problem is to choose the optimal rate of taxation in order to take more revenues with little negative on the economic growth. Keho (2010), in New Zealand using the methodology of Scully to determine the optimal tax rate, finds evidence of U-relationship, like Laffer suggests. Scully (1995) finds the optimal tax rate of the USA to be about 21.5 and $22.9 \%$ of GDP. Branson and Lovell (2011), using a linear programming model, find a mean growth maximizing tax burden of $22.5 \%$ of GDP.

Although we can create an idea about the optimal level of tax rate, the implementation of it in practice is another part of the chain that decidedly determines the effectiveness of it. By the other hand, the monetary policy is more flexible in short run and can produce new impulse on the economy, especially if the bad loan are in high level showing not a favorable situation for the firms and the whole economy, like Albania is.

\section{Some Economic Aspect of the Business Environment in Albania}

The economic theories suggests that when the economy of the country go to recession, the government can change the rate of interest (and this can do with no high cost on the decision process), with the aim to reduce it and to support the business. According to the recent data on business performance, despite that Bank of Albania has reduce the interest rate, business face difficulties. This is obvious by the questionnaire where $41.5 \%$ of the business which are asked, claim that Bank of Albania, as an important institution on the performance of overall of economy, is going to play an indifferent role during those 5 recent years. Only $18.26 \%$ of business claims that its role is extremely unfavorable. (Please see at the below Chart 1.) 
Chart 1. The opinion of Albanian business about the role of Central Bank in the performance of the economy

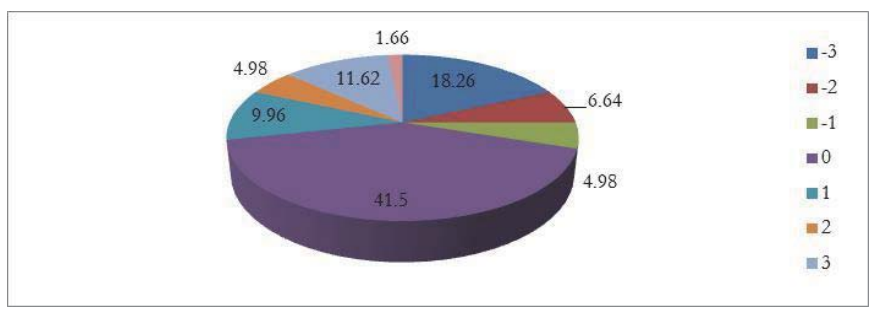

This attitude is reflected also into the private banking system operations which, calculating the economic risk, prefers to give loans to government than to private business, where $24.9 \%$ of those claims that banking system have an indifferent role on the credit process of business. Its attitude is a little comprehensive, taking into account that in many cases the government has take loans by the banks more than private business, especially 5 years ago.

During the time, where the economic regional situation (the Greek crisis is sensitive over the all euro zone), is going to be more present on the performance of Albanian business and where the level of bad credits is increased, normally the banks prefer to not give loans to private business.

Although in the recent years, some banks have made good offers to them, in reality the level of credits is going to be lower year by year, according to the Bank of Albania. Also, those business that have taken loans, have preferred it in the country currency ALL (about 79.68\%) than in foreign currency -almost EURO (about 19.92\% of those, please see at the below Chart 2.)

Chart 2. The preference of currency loan by the business

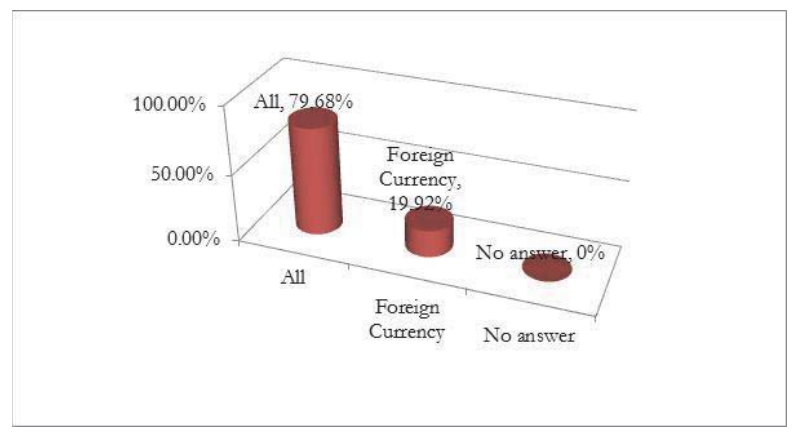

The crisis that has devaluated the country currency ALL, but also EURO currency, makes the situations for them more problematic. That's because the firms are not in able to pay the loans, meanwhile the money liquidity is a crucial problem in the recent years. By the questionnaire, $63.08 \%$ of asked firms tell that have had a reduction on their activity rate because of the lack of funds. A sign that indicates that the economy is going to recession and the economic problems like inflation and unemployment which have a great impact on the people's social life, will be more evident in the recent years. More than the lack of funds, it's the reduction of aggregate demand that has led to their contraction.

According to the questionnaire, $73.04 \%$ of the business versus $23.24 \%$ of those, doesn't think that the economic situation in Albania will stimulate them to expand their activity or to start from scratch into other activities. It seems that the demand for goods and services in the country is very low. Taking into account the level of wages and the rate of inflation in the country, this is reasonable.

Although that government has taken periodically facilitating fiscal steps for business ( bring to mind the fiscal amnesty), most of the business, which $81.34 \%$ of them belongs to the category small business and only $16.6 \%$ of them pays profit tax, claims that those instruments and the actual level of taxes has not stimulated, in $78.02 \%$ of cases. Actually, the VAT rate in Albania is $20 \%$, meanwhile in other countries is lower. ( please see the below Chart 3.). Anyway, The reduction of VAT rate can increase the consumtion on short run, but not the investment in the long run, which can rise the growth rate of economy. 
Chart 3. The opinion about how much the actual tax level has stimulate the Albanian business

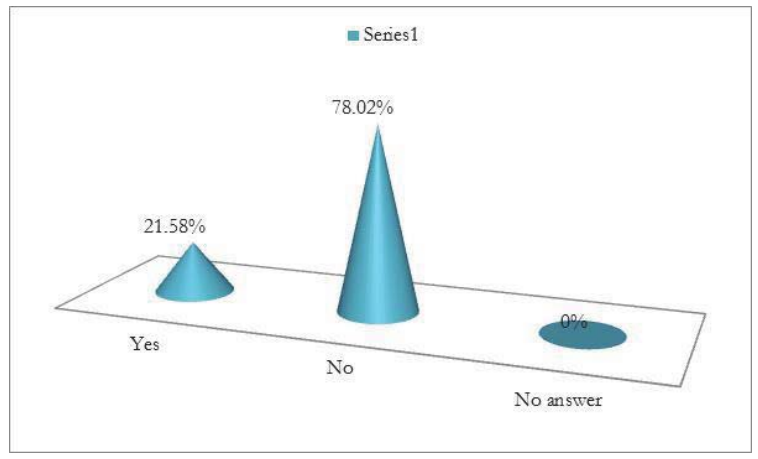

Moreover, the existence of many kind of taxes, not only makes them confuse, but also rise their costs. For that reason, $81.34 \%$ of them preferred regrouping taxes as a good alternative which going to reduce the bureaucratic procedures.

Now the procedure has change. With the new fiscal computer system, all the firms knows in real time their liability and can do everything by the computer (any fiscal invoice, administration issues etc), avoiding so the costs and time of bureaucratic procedures in tax administration institute). Also, all the taxes are going to be paid only in an account, so the coordination with all institutions will be with efficiency.

In order to reduce the informal economy, the government has forced business to use the fiscal cash drawer. Those who haven't it, or have employee that works in "black labor market" will be punishment. Some of them doesn't agree with that fact because:

- Costs a lot to buy the fiscal cash drawer

- Business claim for a non good operations of fiscal cash drawer

- The existence of fiscal cash drawers more over has led to "a bloom" of the business which sell those, rather than have contributed into the reduction of the inappropriate actions in order to have a normal performance of the economy by the economic agents.

Despite those opinions, the aim of using fiscal cash drawer is clear: the reduction of informal economy in order to formalize the economy and especially the labor market in Albania. This is a process that takes time and the results will be seen over the years but is necessary.

Asking which are the most three problems for them, $29.88 \%$ claim the taxation and the $14.94 \%$ the inspection process which makes them frustrated (please see the below Chart 4). The third problem is the non correct competitive environment.

Taking into consideration the fact that the most business are in the category of small business, so the economic game with rules that are broken by most of business, makes the performance of overall economy not in good level.

Chart 4. The most crucial problems related to the normal progress of business activities

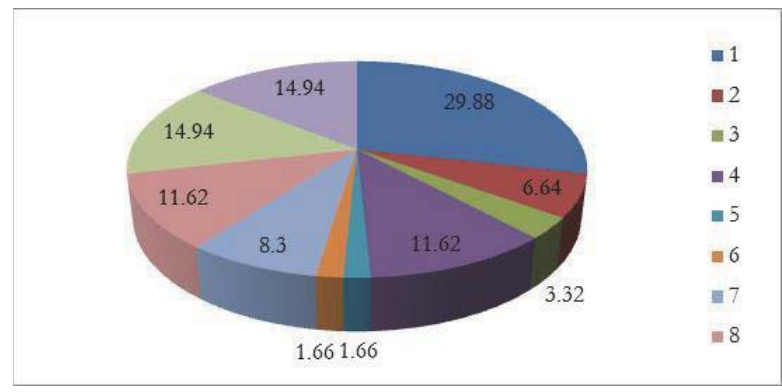

The fiscal steps undertake on those 2 recent years, can only create a favorable competitive environment, however on this direction the institutions have a lot to do. 


\section{Data Presentation and Analysis}

In order to see which of the two policies, monetary or fiscal, are the most that influence on the growth of Albanian business, trying to formulate the regression equation, will be taken in consideration the questions P15, P4 and P 33 of the questionnaire. Where:

P15-Did you get a reduction in your activity or have cancelled the project because of the lack of funds?

P33-Did you think that the actual level of tax had made you more powerful in your activity?

P4-Have you made an application for credit funds to banks? If no, what are the reasons?

The general regression equation has the coefficients as follow (taking into account the log variables):

Table 1. The value of parameters in the regression equation

\begin{tabular}{|c|c|c|c|c|}
\hline Term & Coefficients & SE Coefficients & T & P \\
\hline Constant & 0.666667 & 0.668529 & 0.99721 & 0.330 \\
\hline P33 & 0.266667 & 0.351531 & 0.75859 & 0.456 \\
\hline P4 & 0.066667 & 0.037811 & 1.76315 & 0.042 \\
\hline
\end{tabular}

Chart 5. The distribution of residual plots of the independent variable on the regression equation

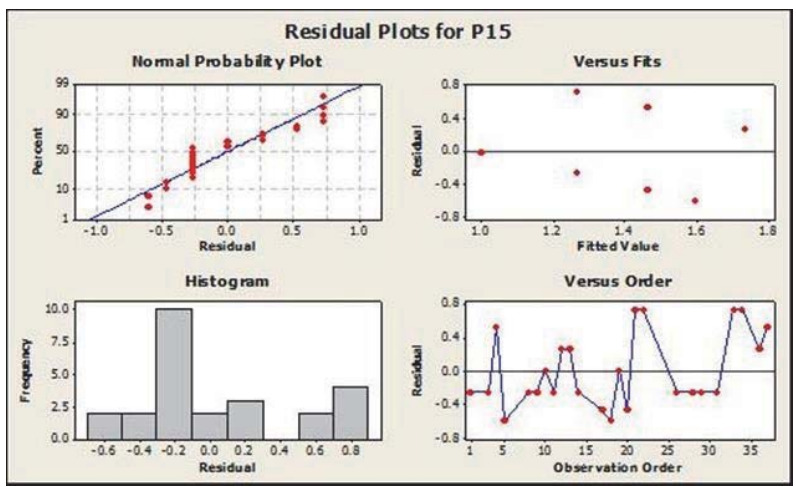

By the examination of the table's coefficient, is clearly that the variable which influence a lot is P4 (since its p-values is $0.042<0.05$ ). This shows that, under the economic circumstance, the politic that is more important to the growth of firms is monetary policy. By the results of the survey, is noted that many business see the capital growth as a favorable variable for their simulation. But, banking system don't support them in this regards. According to the respondents of the questionnaire, the loans are taken more in country devise ALL and little in Euro. Also, some fiscal instruments as online tax payments, fiscal case, are seen by the business as necessary instruments but not effective in today's conditions. It's not to forget that most of the business are been identified as small business so many tax types only rise the bureaucratic costs and makes them confused for normal operation, while reducing the cost is the only manner to survive in the market.

Also, according to FMN (2003), in the development countries, the opportunity to have excess surplus is going to be reduced meanwhile the level of fiscal debt burden goes towards 50\% of GDP. This means that, if the debt burden is more than $50 \%$ of GDP, the behavior of fiscal policy is unclearly and doesn't guarantee the financial ability payment without increasing the level of debt. This is evident in the survey where the fiscal policy is not a significant variable.

Into the conclusions of the survey realized by Bank of Albania Shijaku, G (2013) is stressed the fact that the fiscal policymakers analyzed the performance of the previous variable's surplus to the function of decision making process. Also, the results show that the reaction of fiscal policy is pro-cyclical, making not in good position the fiscal policy. Meanwhile, the monetary market is more flexible, its instrument can help to achieve the target macroeconomic variables more quickly in time and with no more negative access in some other variables. In the regression of the article is clear that, taking a good direction of those variables, the influence in the overall performance of Albanians business will be better. 


\section{Conclusions}

Problems of the Albanian business are conditioned not only by the performance of the abroad economy, but also by the performance of the fiscal and monetary policies undertaken in the country. By the results of the survey, is necessary to be taken some steps in order to improve the climate of the business. Stimulating the private sector is necessary for having economic growth in the future, because is the economic agent that influences more in the reduction of the unemployment rate. In order to have long run economic growth, the studies suggests to be undertaken those polices that stimulate the investments and the variables of supply side. According to the questionnaire, the results stressed the fact that monetary policy is more efficient that fiscal policy in the current situation in Albania. But, reducing the interest rate is not the only way to stimulate economy, despite the survey which stressed the rise of capital as a good way for their growth. That's because the banking system does not acts in the right measure. The growth of bad loans is a fact that justifies them, but also is an indicator of their badly performance.

The Administrative Court ( which is present more than 2 years) is a good step into the creation of a favorable climate of the business in the country, reducing in this way the number of theft, frauds of the business administrators etc. The strengthening of it is crucial for the overall performance of economy. Stimulation of aggregate demand in the country is necessary to have a favorable climate of the business. The government has to do something on this way.

\section{References}

Arnold, J., Brys, B., Heady, C., Johansson, A., Schewellnus, C., \& Vartia, L., (2011). Tax Policy for Economic Recovery and Growth. Economic Journal, 121(550), 59-80

Barro, R. (1979). On the Determination of Public Debt. Journal of Political Economy, Vol.87, No.5, pp: 940-971;

Carlin, Wendy, Fries, S., Schaffer, M., Seabright, P., (2001). Competition and Enterprise Performance in Transition Economies: Evidence from a Cross-Country Survey. EBRD Working Paper No. 63;

Dobrescu, G. and Salman, L., (2011). Fiscal Policy During Absorption Cycles. IMF Working Paper, WP/11/4;

Djankov, Simeon, Murrel, P., (2000). The Determinants of Enterprise Restructuring in Transition: An Assessment of Evidence. World Bank, Washington D.C;

Laffer A.B (1981). Supply-Side Economics. Financial Analysts Journal, 37(5), 29-44

Laubach, Th., (2009). New Evidence On the Interest Rate Effects of Budget Deficits and Debt. European Economic Association, Vol.7, No.4, pp: 858-885;

McBride, W., (2012). What is the Evidence of Tax and Growth? Tax Foundation Special Report 207

Ministria e Financave (2010). Programi Ekonomik dhe Fiscal per 2011-2013, MoF Shqiperi, Shkurt 2011;

Muco, M., Sanfey, P., Taci, A., (2003). Inflation, Exchange Rate and The Role of Monetary Policy in Albania. EBRD;

Scully, G W.,(1995). The "Growth Tax" in the United States. Public Choice, 5(1/2):71-80

Report (2003). Albania Enterprise Policy: Performance Assessment .OECD;

Turrini, A., (2008). Fiscal Policy and the Cycle in the Euro Area: The Role of Government Revenue and Expenditure. Economic and Financial Affairs.

Shijaku, G., (2012). Qendrueshmeria e Politikes Fiskale: Rasti i Shqiperise. Banka e Shqiperise, Working Paper 06 (56);

Schoemann, N. \&Koch, S,. (2005). The South African Tax Mix and Economic Growth South. African Journal of Economics and Management Sciences, 8(2), 201-209; 